\title{
BRASIL BANHADO EM SANGUE
}

\section{Brazil Bathed In Blood}

Guilherme Sachs

Mestre em Estudos da Linguagem (UEL) Professor do Instituto Federal do Paraná, Campus Telêmaco Borba) guilherme.sachs@ifpr.edu.br

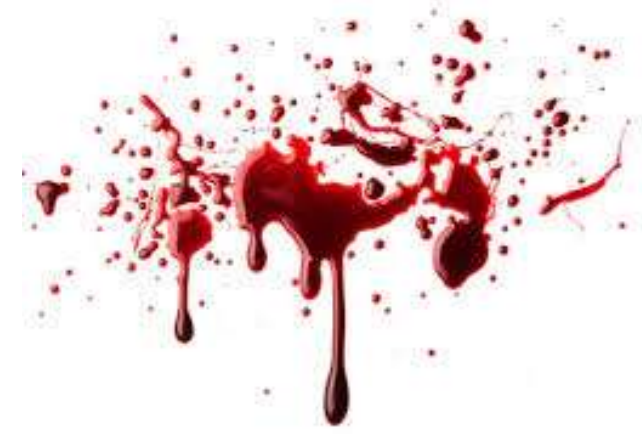

Sangue indígena

Sapanawa, Yanomami, Caingangue

Brasil banhado em sangue

Brasil banhado em sangue

Sangue homossexual

É morte casual!

Brasil banhado em sangue

Sangue de traveco

Morta na saída do boteco

Brasil banhado em sangue

Sangue feminino

A vítima é o assassino!?

Brasil banhado em sangue

Sangue de puta

Por desvio de conduta

Brasil banhado em sangue

Sangue negro, de preto

Afinal, são tudo de gangue

Brasil banhado em sangue

Sangue de pobre

Tem até polícia que encobre

Brasil banhado em sangue

Sangue de quilombola
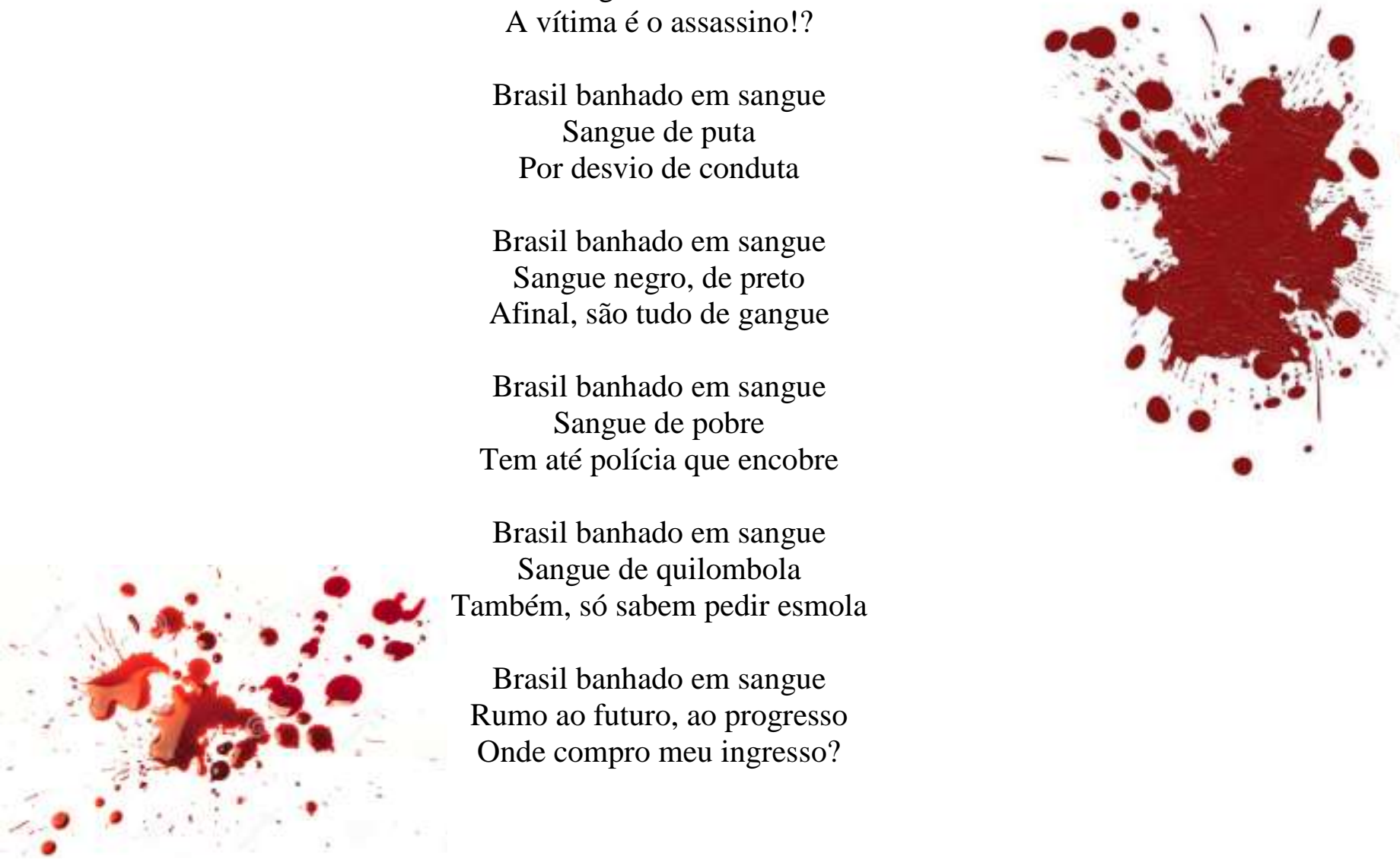

Também, só sabem pedir esmola

Brasil banhado em sangue Rumo ao futuro, ao progresso

Onde compro meu ingresso? 